\section{The impact of store satisfaction on consumer responses in out-of-stock situations}

\author{
Aleksandar Grubor \\ Nikola Milicevic \\ Nenad Djokic \\ University of Novi Sad, Faculty of Economics in Subotica, \\ Department of Trade, Marketing and Logistics, \\ Subotica, Republic of Serbia
}

Received on

07/11/2016

Approved on

04/24/2017

Responsible editor:

Prof. Dr. Guilherme Shiraishi

Evaluation process:

Double Blind Review

\begin{abstract}
Purpose - The purpose of this paper is to test a conceptual model by means of which we try to establish the influence of store satisfaction and other variables (gender, mobility and availability of alternative stores) on consumers' responses to out-of-stock (OOS) situations.
\end{abstract}

Design/methodology/approach - The authors used a standardized questionnaire to gather data on consumer responses to OOS and then analyzed determinants including store satisfaction (for which reliability, validity and unidimensionality were tested). The survey was conducted in the four largest cities in Serbia. All respondents were interviewed randomly, through telephone calls, whereby 392 responses were gathered. The established hypotheses were tested by means of a multinomial logit model with the use of marginal effects.

Findings - The results show that store satisfaction significantly affects three out-of-stock responses (store switching, postponement and product switching), whereas, positively in the case of product switching and postponement and negatively in the case of store switching. The results also show that store satisfied consumers, regardless of other factors, are not likely to switch stores in out-of-stock situations.

Originality/value - As well as managerial implications, this paper included store satisfaction as an antecedent of consumer OOS responses for the first time. In addition, the impact of this variable on OOS responses was analyzed at both levels of the availability of alternative stores, gender and mobility.

Keywords - Out-of-stock; consumer responses; store satisfaction.

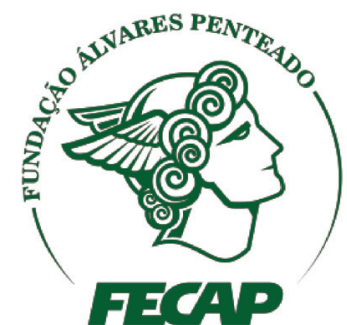

Review of Business Management

DOI: $10.7819 /$ rbgn.v0i0.2436 


\section{Introduction}

Forming and carrying inventories basically results from the wish to ensure the continuity of a company's business operations, in order to secure protection against disruption to supplies, or price volatility, and appropriately meet demands (Blinder \& Maccini, 1991). Bearing in mind that inventories are a substantial part of business assets both in trade and in manufacturing companies, they account for comparatively high financial assessments. According to the report by the World Bank (2010), inventory costs make up $2.1 \%$ of the United States' GDP and up to 5\% of Brazilian GDP.

However, as well as the costs caused by the "existence" of inventories, most companies, especially retailers, often confront them with those related to out-of-stock situations. When a consumer cannot find a desired product in the store, both the retailer and the supplier can suffer certain consequences. Thereby, almost any consumer OOS response may produce adverse effects. According to Roland Berger Strategy Consultants (2003), because 9\% of consumers who face an out-of-stock situation cancel their purchases, retailers and manufacturers lose over 4 billion Euros every year. In addition to cancellation, other responses related to brand switching or item switching (i.e. purchasing cheaper ones) as well as store switching, can also reflect negatively through a reduction in sales (Ehrenthal, Gruen, \& Hofstetter, 2014). Overall sales losses caused by out-of-stock amount to $3.9 \%$ at the global level, $3.8 \%$ in the United States, and 3.7\% in Europe (Gruen, Corsten, \& Bharadwaj, 2002). This percentage is even higher in other regions, including South America. Sale losses due to stock-outs in Colombia are estimated at $5.3 \%$ of total sales (Barajas, 2004). According to the Brazilian association of supermarkets (Abras), the OOS problem is responsible for $42 \%$ of all sale losses in the retail sector (ECR Brasil, 2004). In this regard, the study of ECR Brasil (2007) has shown that $37 \%$ of consumers who would substitute the store in the case of out-of-stock cost an average Brazilian supermarket R \$ 265,375.00 in lost sales. On the other hand, in Argentina, sale losses due to this problem amounted to 502 million pesos ( $\mathrm{R} \$ 496$ million) in 2003 (Oliveira, 2004).

In addition to direct sales losses, an OOS situation can cause indirect negative effects as well (Gruen et al., 2002; Ehrenthal et al., 2014). Higher inventory holding costs, inaccurate information exchange and sales planning are just some of them. However, to retailers, one of the biggest issues is related to a decrease in store loyalty (Ehrenthal \& Stolzle, 2013), which can have long term consequences on business performance. Even though the consumer switching rate is still undocumented, the annual cost of permanent shopper loss to competitors is estimated at US $\$ 1$ million per every 200 shoppers (Gruen \& Corsten, 2007).

Due to considerable costs caused by out-of-stock situations in retail stores and neglecting these by retailers (Institute of Grocery Distribution, 2007), this article presents the fundamental characteristics of this problem. Bearing in mind that OOS effects primarily depend on consumer response, special attention was given to its contributing factors. Having analyzed the results of previous studies, we established a conceptual model with emphasis on store satisfaction as a store-related antecedent. As this variable was proven to be one of the key determinants of consumer purchase behavior (Seiders, Voss, Grewal, \& Godfrey, 2005), it was examined in the context of OOS responses in this paper. After interpreting the results, some guidelines for retailers as to mitigating the negative consequences of OOS situations are presented.

\section{Defining out-of-stock situations}

There are many definitions and indicators that can be used for describing out-of-stock situations. According to Jacobs, Berry, Whybark and Vollmann (2011), stock-out can simply be 
defined as a situation in which demand is not met and the order is cancelled. To them, OOS differs from a backorder, a situation in which the order is held and fulfilled later, after the replenishment cycle is over and inventories for the item are available again.

Roland Berger Strategy Consultants (2003) offered a much more complex explanation for OOS. They presented three different forms of OOS: classical, dual placement and delisting out-of-stocks. Classical OOS means that the item is not available on the labelled shelf-place. Dual placement OOS occurs when the item can be found on the shelf but not on the other placement site (for example, a special place in the case of promotion) and vice versa. Delisting OOS appears when consumers cannot reach the desired item because it was taken by store staff.

Holman and Buzek (2008) had a similar approach to defining out-of-stocks. According to them, there are five specific OOS types, all representing the situation wherein a consumer who enters the store to buy a specific product leaves it without making the purchase. These types include (Holman \& Buzek, 2008):

a) empty shelf - when the consumer cannot find the specific product on the marked shelf space;

b) stock present, but no help available - when the consumer can see the product, but cannot reach it (because it is locked or placed on a high shelf), while there is no store staff help available;

c) stock present, but no access - in this case the consumer finds store staff to help, but they cannot get the product either (for instance, they do not have access to the location where the product is stocked);

d) promo price mismatch - the consumer does not make the purchase because the price/offer in the store does not match that advertised;

e) any other reason (except lower expenses and the four reasons above) because of which the consumer decides to leave the store and not buy the desired product.
To Bayle-Tourtoulou, Laurent and Macé (2006), classical OOS definitions are too myopic from the sellers' perspective, because they do not cover the economic side of stock-outs. According to these authors, effective definition of OOS should include elements such as OOS frequency, duration, occurrence at a time of low or high store traffic, or importance of the item in the category. Thereby, a long stock-out of a major item during a rush hour should be much more important to a retailer then a brief OOS for a minor item at a slow hour, during which no sales are lost (BayleTourtoulou et al., 2006).

In this context, Gruen and Corsten (2007, p.1) have identified two fundamental concepts: OOS event and OOS attributes. While the former refers to "what an out-of-stock is", the latter is related to aspects of its description and calculation as an out-of-stock rate, such as number of occurrences over time, number of simultaneous occurrences, duration, lost sales etc. In addition to these concepts, Gruen and Corsten (2007) distinguished three OOS measuring methods:

a) manual auditing method;

b) POS sales estimation; and

c) perpetual inventory aggregation.

In the first, direct approach, store auditors visits stores over particular time periods in order to find shelf gaps (Roland Berger Strategy Consultants, 2003). Their main task is to identify out-of-stocks and measure availability of reference items by physical counting. According to Fernie and Grant (2008), third-party service providers can be engaged to carry out in-store OOS checks for these operations.

For measuring out-of-stock levels, retailers can also use POS sales, i.e. store scanner and inventory data (Gruen \& Corsten, 2007). By analyzing them, they can identify partial (when sales of a selected product are abnormally low) and total out-of-stocks (when there are no sales of a selected product) (Roland Berger Strategy Consultants, 2003). However, besides its benefits in terms of cost and availability of information (Ettouzani, Yates, \& Mena, 2012), one of 
the major limitations of this method refers to difficulties in the application for SKUs that sell slowly (Gruen \& Corsten, 2007).

Opposite to the first two, the third "PI" measurement method based on the use of Perpetual Inventory data (when sales $=0$, the item is OOS) usually applies only for store outof-stocks (when the item is not physically available in the store) in lower volume store formats (Gruen $\&$ Corsten, 2007). Because of these reasons and its low accuracy, this method should be combined with the manual approach.

In spite of the fact that methods based on POS data are developing and attracting the attention of retailers and researchers (Hausruckinger, 2006; Milicevic \& Grubor, 2015; Papakiriakopoulos \& Doukidis, 2011), in most OOS studies the out-of-stock rate was measured through manual auditing (Gruen \& Corsten, 2007). According to Gruen et al. (2002), the average worldwide OOS rate is estimated at $8.3 \%$, a bit higher than the average US (7.9\%) and a bit lower than the average European outof-stock rate $(8.6 \%)$. Compared to these rates, the situation is much better in Asia-Pacific and Australia/NZ regions, where the average out-ofstock levels are 5\% and 4.4\% (ECR AP, 2012). On the other hand, higher OOS rates are recorded in South America. According to Ribeiro (2008), in Argentina and Chile, the average OOS rate amounts to $17.15 \%$ and $14.3 \%$, respectively. Its level is lower in Colombia, where Barajas (2004) recorded the average stock-out rate of $9.2 \%$. In Brazil, the results of the study conducted in 2004 by ECR Association Brazil in partnership with the Brazilian Association of Supermarkets (Abras) and ACNielsen, revealed an average outof-stock rate of $8 \%$ (ECR Brasil, 2005). Later measurements have shown that this value hasn't changed a lot, whereby Vasconcellos and Sampaio
(2009) reported that it was $8.3 \%$, while Catuogno (2013) stated that the average OOS rate in Brazil amounted to $7.8 \%$.

Besides countries and regions, out-ofstock levels differ among product categories as well. Thereby, in Europe, OOS rate for product categories like fresh ready meals, confectionery and ice cream exceeds $10 \%$, while for categories such as hair care, baby care and cosmetics, it is under 4\% (Roland Berger Strategy Consultants, 2003). In Brazil, results of the research of Azevedo and Araújo (2004) pointed that bread and sugar categories had the highest OOS rates, over 10\% ( $11.6 \%$ and $10.8 \%$ respectively), contrary to the dairy category, whose OOS rate was $6.8 \%$.

However, according to Holman and Buzek (2008) all these out-of-stock rates are much lower than the "true OOS rate." Partially because of the use of a more expanded definition of out-ofstocks, these authors calculated the OOS rate of $17.8 \%$, because of which they warned retailers, who are, according to their opinion, "in denial about out-of-stocks."

\section{Consumer responses to out-of- stock situations}

Stock-out in a retail store places consumers in a situation wherein, in addition to wasting time, money and energy, they fail to fulfil their goal and do not buy items of the desired shape, type and size. This is also one of the most frequent problems they face when shopping, as confirmed by the results of several studies (Roland Berger Strategy Consultants, 2003; Supermarket Guru Consumer Panel, 2011). Consequently, stockouts create a feeling of dissatisfaction, which can later have a negative effect on the retail's business performance. 


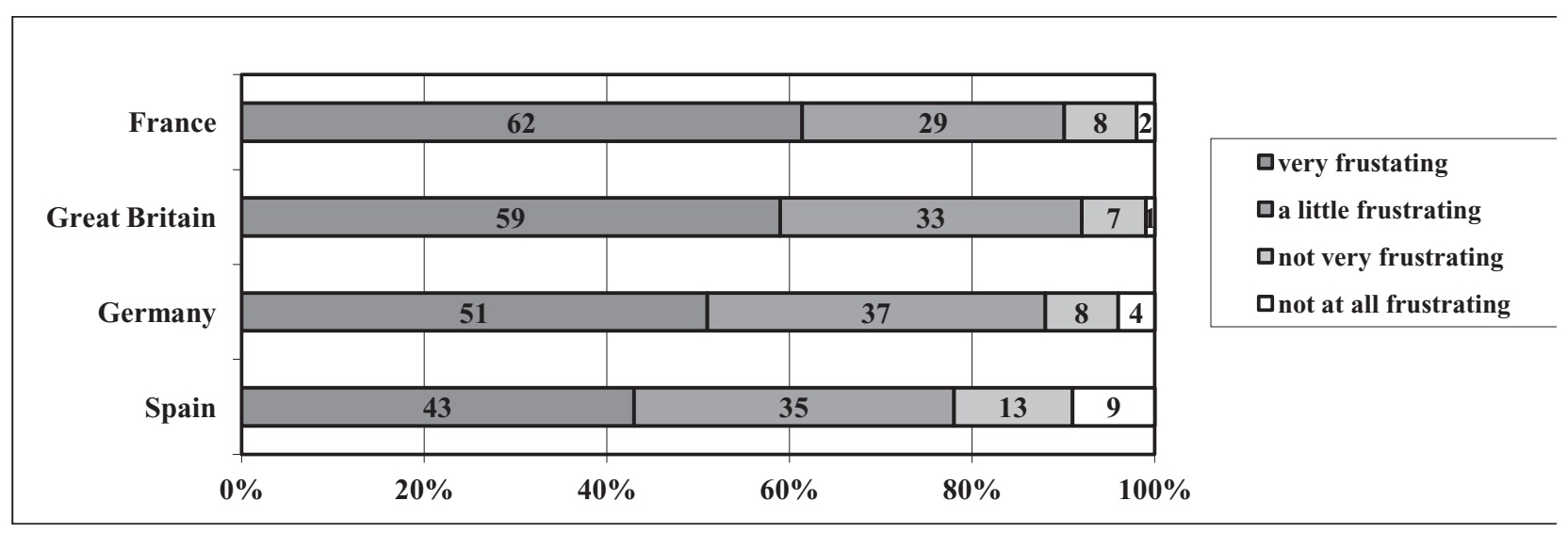

Figure 1. Consumer feelings in OOS situations.

Note. Retrieved from "On-shelf availability making-it-happen together" by K. Olofsson, 2006.

As seen in Figure 1, the largest number of consumers feels very frustrated when faced by OOS events. This percentage is highest in France, amounting to $62 \%$, followed by $59 \%$ in Great Britain, $51 \%$ in Germany and $43 \%$ in Spain. A significant number of consumers is "a little frustrated" by the inability to find the desired product. In all countries, it ranges from $29 \%$ in France to $37 \%$ in Germany. The lowest percentage accounts for consumers who do not regard stockouts as a major problem. It does not exceed 10\%, with only $1 \%$ in Great Britain. Therefore, over $90 \%$ of consumers faced with the stock-out issue feel a certain degree of frustration.

If they cannot find the desired item in a retail store, consumers may react in various ways. The first studies of consumer responses to OOS situations appeared in the second half of the $20^{\text {th }}$ century (Peckham, 1963; Progressive Grocer, 1968). This period also saw the first classification of their responses, based on which consumers in stock-out situations may opt for substitution (of the item, the brand or the retail store), giving up or delaying the purchase. The basis of the SDL (Substitute, Delay or Leave) classification was established by Walter and Grabner in 1975, analyzing the behavior of consumers faced with stock-outs in beverage retail stores. Over the subsequent period, many authors based their researches on the above mentioned SDL responses (Campo, Gijsbrechts, \& Nisol, 2000; Emmelhainz, Emmelhainz, \& Stock, 1991; Schary \& Christopher, 1979; Verbeke, Farris, \& Thurik, 1998; Zinn \& Liu, 2001). In 2002, Gruen et al. (2002) presented one of the most comprehensive OOS reports (made up of 52 studies with over 71,000 respondents), analyzing five consumer responses:
a) item switching;
b) brand switching;
c) store switching;
d) cancellation;
e) delay purchase.

In addition to the above listed responses, Sloot, Verhoef and Franses (2002) added another response - category switching - when the consumer opts for a product from another category. Verhoef and Sloot (2006) classified all six consumer responses into two groups: buying (item, brand or category switching) and not buying a substitute (store switch, purchase delay or cancellation). However, most other studies tend to analyze the five above listed responses. The table below presents the results of some. 
Table 1

\section{Consumer responses to OOS}

\begin{tabular}{|c|c|c|c|c|c|c|}
\hline \multirow[b]{2}{*}{ Authors } & \multirow[b]{2}{*}{ Regions } & \multicolumn{5}{|c|}{ OOS responses } \\
\hline & & $\begin{array}{c}\text { Store } \\
\text { switching }\end{array}$ & $\begin{array}{c}\text { Delay } \\
\text { purchase }\end{array}$ & $\begin{array}{c}\text { Item } \\
\text { switching }\end{array}$ & $\begin{array}{c}\text { Brand } \\
\text { switching }\end{array}$ & Cancell. \\
\hline Gruen et al. (2002) & Worldwide & $31 \%$ & $15 \%$ & $19 \%$ & $26 \%$ & $9 \%$ \\
\hline Roland Berger Consultants (2003) & Europe & $21 \%$ & $17 \%$ & $16 \%$ & $37 \%$ & $9 \%$ \\
\hline Azevedo \& Araújo (2004) & Brazil & $36 \%$ & - & $3 \%$ & $53 \%$ & $8 \%$ \\
\hline $\begin{array}{l}\text { Sudarevic, Milicevic, Pupovac, \& } \\
\text { Vukmirovic (2012) }\end{array}$ & Serbia & $21 \%$ & $4 \%$ & $23 \%$ & $47 \%$ & $5 \%$ \\
\hline
\end{tabular}

In EU countries, as well as in Brazil and Serbia, the majority of consumers $(37 \%, 53 \%$ and $47 \%$ ) respond to stock-outs by opting for buying another manufacturer's product (i.e. brand substitution). A significant percentage of consumers faced by OOS choose store switching as well. However, opposite to Brazil, where only $3 \%$ of consumers will switch items, in Europe this percentage is much higher, exceeding 15\%. Still, if out-of-stock situations occurs repeatedly, the consumer response may change, as shown in Figure 2.

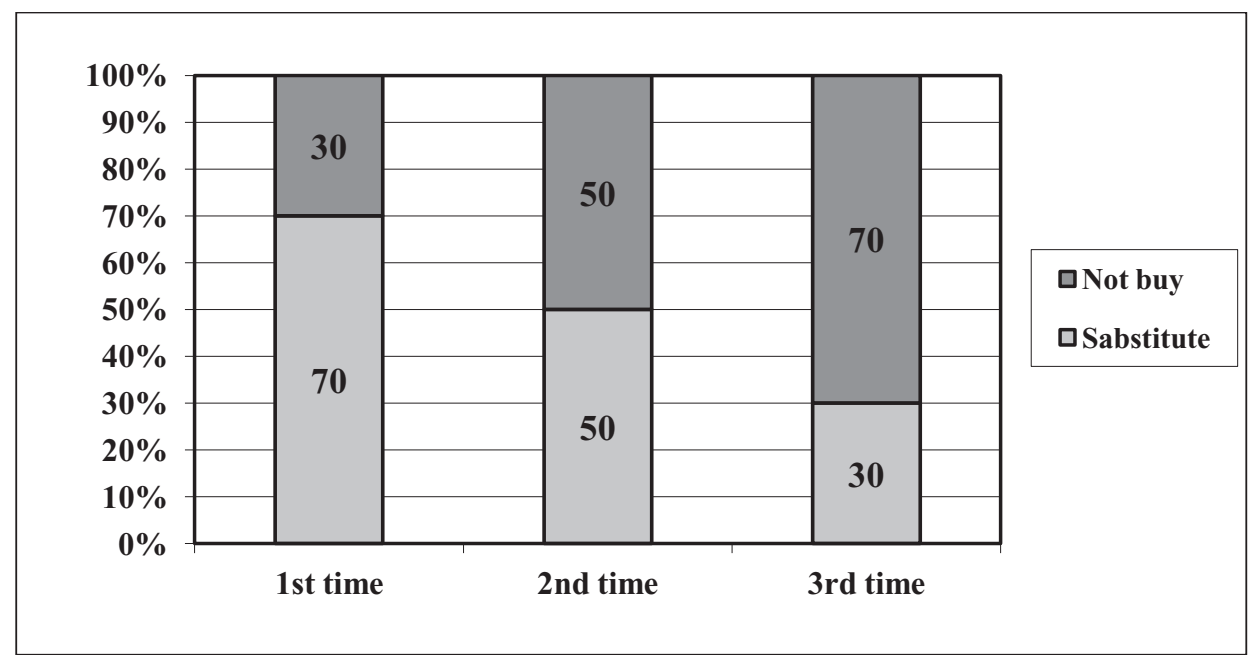

Figure 2. Response to repetitive out-of-stocks.

Note. Retrieved from "Retail out-of-stocks a worldwide examination of extent, causes and consumer responses” by T. Gruen, D. Corsten, \& S. Bharadwaj, 2002.

If an OOS situation repeats itself for the second time, the number of consumers opting for substitution of the brand or item will fall from $70 \%$ to $50 \%$. On the other hand, the percentage of those willing to switch stores or cancel the purchase will increase from 30 to $50 \%$. Thereby, after the third "disappointment", the likelihood of brand or item substitution will fall to $30 \%$, while its value for store substitution and cancellation will reach $70 \%$. These changes in consumer responses toward store switching have been confirmed by the results of other studies as well (Roland Berger Strategy Consultants, 2003; Walter \& Grabner, 1975). Bearing in mind that this response may lead not only to decreased revenue, but also to potential loss of 
loyal consumers, special attention should be given to factors influencing their decisions.

\section{Antecedents of consumer response to out-of-stock situations}

Consumer responses to OOS situations are influenced by a large number of factors. Zinn and Liu (2001) grouped them into consumer, situational, demographic and perceived store characteristics. Most other studies (Campo et al., 2000; Helm, Hegenbart, \& Endres, 2013; Sloot, Verhoef, \& Franses, 2005; Verhoef \& Sloot, 2006) included product characteristics as well, while demographic characteristics were usually lumped in consumer-related variables. Thereby, according to Sloot et al. (2005), all antecedents can be classified into four main clusters: product-related variables, store-related variables, consumer-related variables and situation-related variables. Later, Verhoef and Sloot (2006) separated brand-related variables from product-related variables.

While product-related antecedents comprise factors that are related to the specific product category, store-related variables comprise factors that are related to store or retail-chain in which the OOS occurs (Sloot et al., 2005). According to Helm et al. (2013), product-related antecedents consist of the following factors: product involvement, buying involvement, brand loyalty, package size, item variants, decision difficulty and acceptable alternatives. In product characteristics, Campo et al. (2000) also included deal proneness, private label purchase and product importance. On the other hand, store loyalty, number of alternative stores and store types represent store-related antecedents (Verhoef \& Sloot, 2006). In addition, store satisfaction may also be considered an important store characteristic, specially when having in mind that it is one of the main predictors of store loyalty (Bridson, Evans, \& Hickman, 2008). Hereby, satisfaction can generally be understood as an overall evaluation based on experience with product or service provider (Homburg, Koschate, \& Hoyer, 2005), influencing purchase intentions and behavior (Seiders et al., 2005).

Out-of-stock responses may depend on consumer-related antecedents, i.e. their psychographic and socio-demographic characteristics (Verhoef \& Sloot, 2006), such as shopping attitude, shopping frequency, general time constraint, age, mobility, price consciousness and quality consciousness (Campo et al., 2000; Sloot et al., 2005). Moreover, attention should be given to certain specifics of the shopping situation, including part of the week, product usage and shopping trip (Sloot et al., 2005). The table below presents the correlations between OOS factors and consumer OOS responses. 
Table 2

\section{OOS study overview}

\begin{tabular}{|c|c|c|c|c|c|c|}
\hline \multirow[b]{2}{*}{ Antecedent } & \multirow[b]{2}{*}{ Variables } & \multirow[b]{2}{*}{ Authors } & \multicolumn{4}{|c|}{ Consumer responses } \\
\hline & & & $\begin{array}{c}\text { Item } \\
\text { switching }\end{array}$ & $\begin{array}{c}\text { Brand } \\
\text { switching }\end{array}$ & $\begin{array}{c}\text { Store } \\
\text { switching }\end{array}$ & Delay \\
\hline \multirow{5}{*}{ Product } & Brand loyalty & Verhoef \& Sloot (2006) & & - & & \\
\hline & Hedonic level & Sloot et al. (2005) & & & + & \\
\hline & Acceptable alternatives & Campo et al. (2000) & + & + & - & - \\
\hline & Number of brands & Sloot et al. (2005) & & - & + & \\
\hline & Brand strength & Verhoef \& Sloot (2006) & + & - & + & \\
\hline \multirow{2}{*}{ Store } & Store loyalty & Campo et al. (2000) & + & + & - & + \\
\hline & Alternative stores & Sloot et al. (2005) & & & + & - \\
\hline \multirow{6}{*}{ Consumer } & Shopping attitude & Campo et al. (2000) & - & - & + & $-1+$ \\
\hline & Decision difficulty & Fitzsimons (2000) & & & - & \\
\hline & Price consciousness & Sloot et al. (2005) & & & - & \\
\hline & Quality consciousness & Sloot et al. (2005) & & - & & \\
\hline & Age & Verhoef \& Sloot (2006) & & - & + & \\
\hline & Mobility & Helm et al. (2013) & & & + & \\
\hline \multirow{2}{*}{ Situation } & Part of the week & Sloot et al. (2005) & & & & - \\
\hline & Buying urgency & Verhoef \& Sloot (2006) & & & + & - \\
\hline
\end{tabular}

In addition to the variables that affect consumer behavior in OOS situations, Campo et al. (2000) expanded their analysis with three basic cost types: substitution, opportunity and transaction costs. Substitution costs represent the potential decrease in benefits caused by poorer performance and/or higher prices of the alternative choice. Transaction costs include all the costs related to seeking and purchasing an alternative product (time- and energy- related costs), whereas opportunity costs occur due to loss of benefits when potential consumption decreases. Campo et al. (2000) related these costs to the following consumer responses: item substitution, package size switching, store switching, postponement and cancelation. Thereby, when substituting an item in an OOS situation, the consumer is faced with substitution and transaction costs, which are highly product-dependent (may depend on availability of acceptable alternatives, item loyalty and decision difficulty). Similar to item switching, package switching can also incur substitution and transaction costs which primarily refer to productrelated antecedents (such as package size). In the case of store switching, substitution costs depend on the availability of acceptable alternative stores, store loyalty, shopping trip and private label purchase (as product-related variable), while the transaction costs of this response are strongly related to consumer antecedents, such as consumer mobility (Campo et al., 2000; Messinger \& Narasimhan, 1997). Mobility, shopping attitude and shopping frequency as consumer-related variables can also affect the transaction costs of purchase postponement. Besides these costs, consumers who postpone or cancel the purchase can be exposed to opportunity costs as well. According to Campo et al. (2000, p. 228), "these costs are product-specific, and/or situation-dependent."

In many previous studies (Campo et al., 2000; Helm et al., 2013; Sloot et al., 2005; Verhoef \& Sloot, 2006; Zinn \& Liu, 2001) out-of-stock responses have been analyzed in the context of store loyalty. Thereby, we did not find any research in which these responses were examined in terms of store satisfaction. Expecting that consumers satisfied with the retail store and 
service will be less likely to opt for switching it in the case of stock-out and more likely to switch products or postpone, the following hypotheses were established:

H1: Store satisfaction negatively affects the probability of store switching.

H2: Store satisfaction positively affects the probability of product switching.

H3: Store satisfaction positively affects the probability of postponement.

As well as store satisfaction, the number of alternative stores, as a store related antecedent, has also been considered in a number of studies. While Verbeke et al. (1998) didn't find this variable relevant, Sloot et al. (2005) pointed out that number of alternative stores had a positive effect on store switching and a negative effect on postponement. Considering this variable as dichotomous, whether there were any alternative stores located in radius of $250 \mathrm{~m}$ (the distance is in accordance to Sloot et al. [2005]) or not, we formulated the following hypotheses:

H4: The availability of alternative stores positively affects the probability of store switching.

H5: The availability of alternative stores negatively affects the probability of product switching.

H6: The availability of alternative stores negatively affects the probability of postponement.

The subject of several out-of-stock studies was the correlation between consumer OOS responses and individual demographic variables (such as gender and age). Verhoef and Sloot (2006) established the existence of slightly significant correlation between age, as consumer-related antecedent, and two out-of- stock responses (brand and store switching). Helm et al. (2013) research results have shown that mature consumers in OOS situations more often opt for item switching, delay or cancellation. On the other hand, in terms of gender, these authors did not confirm the existence of a statistically significant effect of this variable on out-of-stock responses. However, Dholakia (1999) pointed to certain gender differences in shopping behavior, whereas women, contrary to men, see shopping as a pleasure. Therefore, while men prefer to shop quickly with less effort, women enjoy shopping (Das, 2014) and go on more frequent shopping trips (Dholakia, 1999). According to the assumption of Campo et al. (2000), by which consumers with high shopping frequency may decide to look for OOS products elsewhere at a later point in time, we established the following hypotheses:

H7: Female consumers are more likely to switch stores in the case of out-of-stock.

H8: Female consumers are less likely to switch products in the case of out-of-stock.

In addition to gender, according to other studies (Campo et al., 2000; Helm et al., 2013) our research included mobility as the second consumer-related antecedent. According to Campo et al. (2000) consumer mobility may decrease the effort cost of shopping trip in the case of store switching and postponement. However, unlike these authors, who did not confirm the existence of a statistically significant relationship between these variables, Helm et al. (2013) found that car owners would rather substitute stores than cancel their purchases in the case of out-of-stock. Defining consumer mobility as having a car to drive to the store, we developed the hypotheses:

H9: Consumer mobility negatively affects the probability of purchase cancellation.

H10: Consumer mobility positively affects the probability of store switching. 
H11: Consumer mobility positively affects the probability of postponement.

While, referring to hypothesis $\mathrm{H}_{9}$, it's not likely that consumers who use cars as transportation to stores would cancel their purchases, the last two hypotheses $\left(\mathrm{H}_{10}\right.$ and $\left.\mathrm{H}_{11}\right)$ imply that these consumers are more likely to switch stores and postpone their purchase in the case of out-of-stock.

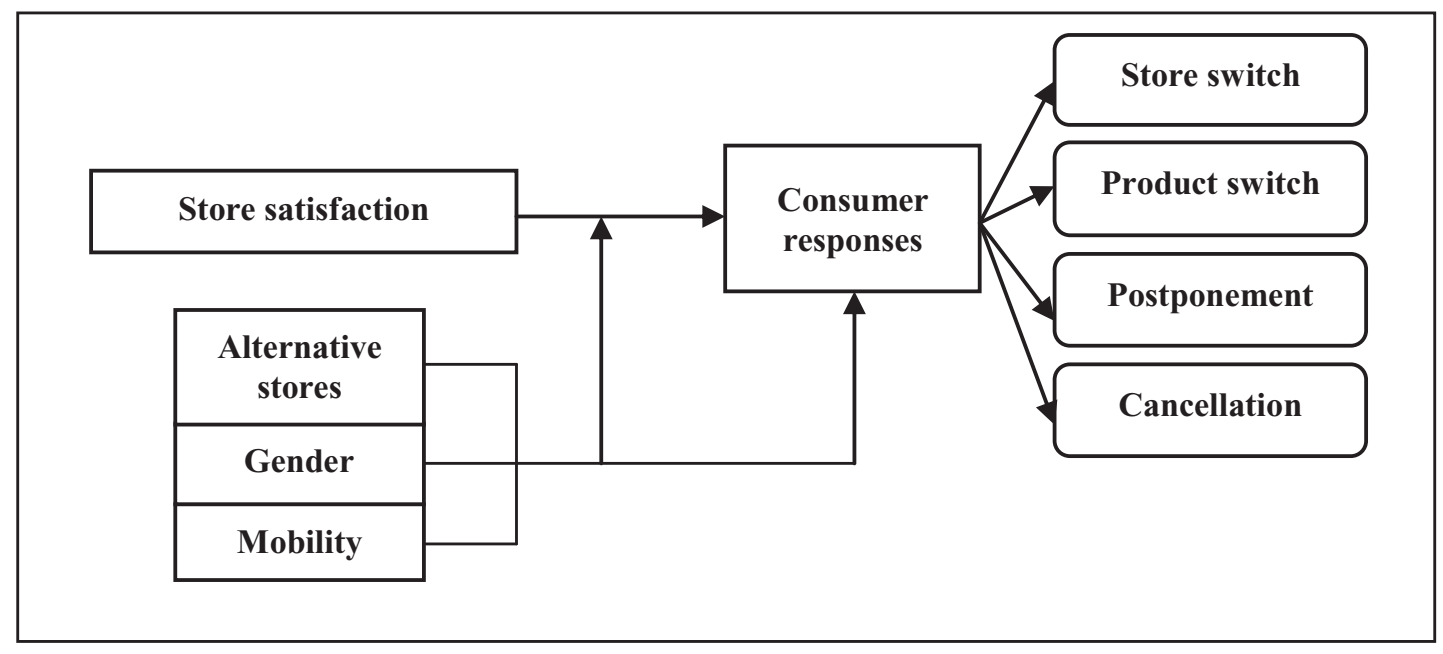

Figure 3. Conceptual model

Furthermore, besides testing the hypotheses, we have also paid attention to the interactions of these variables. In conceptual model presented in Figure 3, the emphasis was on store satisfaction and its relationship with the availability of alternative stores, gender and mobility in the context of out-of-stock responses.

\section{Research methodology}

\section{I Sample}

The survey was conducted in the four largest cities of the Republic of Serbia - Belgrade, Novi Sad, Niš and Kragujevac. All respondents were interviewed randomly, through telephone calls. The great majority $(71 \%)$ of them were female. Having eliminated the incomplete ones, 392 responses were analyzed in 2014 .

\subsection{Questionnaire}

The questionnaire was made up of three parts. The first one referred to the questions about consumers' characteristics: gender (male, female) and mobility (having a car to drive to the store or not).
The second part of the questionnaire referred to the store in which respondent usually performs his/hers purchases. Hereby, the respondents were asked about stores' locations (in purpose of investigating the presence of alternative stores in radius of $250 \mathrm{~m}$ ). Besides, consumer satisfaction with the store was measured by using the adapted scale from the research of Patterson and Smith (2003). The scale considers satisfaction as an overall evaluation based on respondent's experience with the store. It consists of 4 items: I am happy with my decision to buy in this store, My choice of this store was a wise one, I feel good about my decision to buy in this store, Taking everything into consideration, how do you feel about the service you received in this store. Respondents rated these items on a 7-point Likert scale.

For determining whether all the items of satisfaction scale would remain in the analysis, we tested its reliability, validity and unidimensionality. Cronbach's alpha for four items was 0.885 (greater than recommended 0.7 (Nunnaly, 1978)) and omission of none of 
the items could increase its value. The result of Kaiser-Meyer-Olkin test of 0.802 higher than 0.6 (Kaiser, 1970; 1974) and the level of significance of Barthlett's sphericity test of 0.000 (Barthlett, 1954) suggested conducting exploratory factor analysis as appropriate. Maximum likelihood exploratory factor analysis (with Promax rotation) identified one factor with Eigenvalue higher than 1 (Kaiser, 1960), which explained 67.235\% of the total variance. The confirmatory factor analysis results (after correlating the residuals of two items, conducted in accordance with the recommendations of modification) were related to recommendations of $\mathrm{Hu}$ and Bentler (1999) for acceptable model fit and showed it as acceptable (Chi-square/df $=1.212$, $\mathrm{p}$ value for the model $=$ $0.271, \mathrm{CFI}=1.000, \mathrm{GFI}=0.998, \mathrm{AGFI}=0.985$, SRMR $=0.0075$, RMSEA $=0.023$, PCLOSE $=0.474)$. Consequently, all four items of scale for measuring store satisfaction remained in the questionnaire.

The third part of the questionnaire considered consumer OOS responses. Like Sloot et al. (2005), we used a hypothetical stock-out situation. Respondents were asked to choose one potential OOS response (between product switching, store switching, postponement and cancellation). The responses referred to the store in which the respondent usually makes purchases. These responses referred to three product categories: detergents, shampoo and toothpaste. All three categories belong to the group of nonfood products, with a great assortment and a varied range of brands. In addition, they also have approximately similar stock-out rates, ranging from 7\% to 9\% (ECR Europe, 2009).

\section{$5 \cdot 3$ Procedures}

Following other out-of-stock researches (Campo et al., 2002; Helm et al., 2013; Sloot et al., 2005), we tested the established hypotheses by means of multinomial logit model. While dependent variable (OOS responses) was categorical, all antecedents, except store satisfaction, were dummy variables (see Table 3 ).

Table 3

\section{Independent antecedents}

\begin{tabular}{lll}
\hline Antecedents & Concept & Measure \\
\hline Store satisfaction & Satisfaction towards store & $\begin{array}{l}\text { Self-reported scale } \\
\text { based on Patterson \& Smith }(2003)\end{array}$ \\
\hline Alternative stores & Availability of alternative stores & $\begin{array}{l}\text { Dummy variable: } \\
\text { alternative store within the radius of } 250 \mathrm{~m}=1, \\
\text { no alternative store within the radius of } 250 \mathrm{~m}=0 ;\end{array}$ \\
\hline Gender & Gender of respondent & $\begin{array}{l}\text { Dummy variable: } \\
\text { female }=1, \\
\text { male }=0 ;\end{array}$ \\
\hline \multirow{3}{*}{ Mobility } & Transportation shopping mode & $\begin{array}{l}\text { Dummy variable: } \\
\text { car }=1, \\
\text { no car }=0 ;\end{array}$ \\
\hline
\end{tabular}

Additionally, we calculated the marginal effects of each antecedent on all consumer OOS responses, whereas we analyzed store satisfaction at both levels of all other independent variables (Williams, 2012). The statistical software used for this model was the STATA version 13.0.

\section{Empirical results}

Having processed the data, consumer responses were analyzed. Figure 4 presents the four responses (product switching, store switching, postponement and cancellation) across analyzed product categories. 


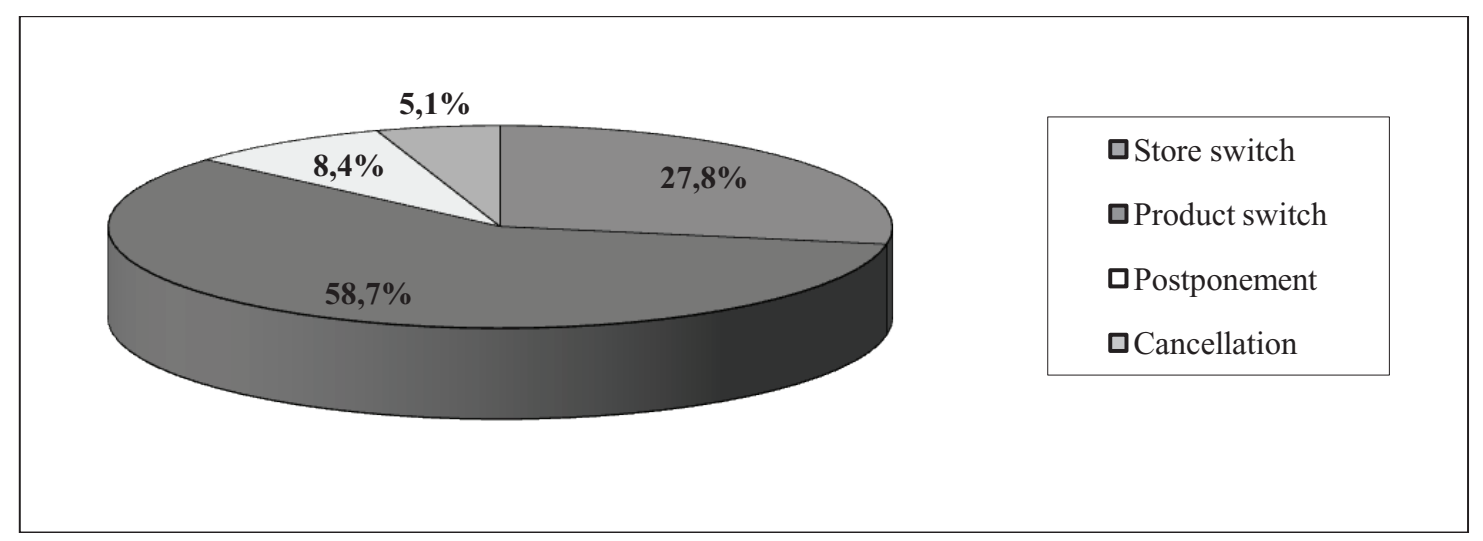

Figure 4. Out-of-stock consumer responses across three product categories.

The most frequent response was product switching (58.7\%), followed by store switching, with $27.8 \%$, and postponement, with $8.4 \%$. The lowest response percentage was cancellation (5.1\%).

In further analysis, the multinomial logit model was applied. The likelihood ratio chi-square $(\chi 2)$ amounts to $32.85(\mathrm{df}=12, \mathrm{p}=0.001)$, which indicates that our model shows strong general significance at $\mathrm{p}<0.01$.

For testing hypotheses, we calculated the marginal effects of analyzed variables. Their values are presented in Table 4.

Table 4

\section{Marginal effects}

\begin{tabular}{|c|c|c|c|c|c|}
\hline \multirow{2}{*}{\multicolumn{2}{|c|}{ Antecedents }} & \multicolumn{4}{|c|}{ OOS responses } \\
\hline & & \multirow{2}{*}{$\begin{array}{r}\text { Store switching } \\
-0.0494^{*}\end{array}$} & \multirow{2}{*}{$\begin{array}{c}\text { Product switching } \\
0.0373^{*} \\
\end{array}$} & \multirow{2}{*}{$\begin{array}{c}\text { Postponement } \\
0.0253^{* *}\end{array}$} & \multirow{2}{*}{$\begin{array}{c}\text { Cancellation } \\
-0.0132 \\
\end{array}$} \\
\hline Store satisfa & & & & & \\
\hline $\begin{array}{l}\text { Alternative } \\
\text { stores }\end{array}$ & available & $-0.0546^{*}$ & $0.0440^{* *}$ & $0.0192^{*}$ & -0.0086 \\
\hline & not available & $-0.0430^{* *}$ & 0.0294 & $0.0328^{*}$ & -0.0193 \\
\hline \multirow{2}{*}{ Gender } & female & $-0.0517^{* *}$ & $0.0406^{*}$ & $0.0260^{* *}$ & -0.0149 \\
\hline & male & $-0.0432^{* *}$ & 0.0290 & 0.0234 & -0.0092 \\
\hline \multirow{2}{*}{ Mobility } & car & $-0.0502^{* *}$ & 0.0284 & $0.0294^{*}$ & -0.0076 \\
\hline & no car & $-0.0476^{* *}$ & $0.0465^{* *}$ & $0.0210^{* *}$ & -0.0199 \\
\hline \multicolumn{2}{|c|}{ Alternative stores } & $0.1001^{* *}$ & -0.0102 & $-0.0526^{*}$ & -0.0372 \\
\hline \multicolumn{2}{|l|}{ Gender } & $0.0901^{*}$ & $-0.1177^{* *}$ & 0.0006 & 0.0270 \\
\hline \multicolumn{2}{|l|}{ Mobility } & -0.0447 & 0.0609 & 0.0386 & $-0.0548^{* *}$ \\
\hline
\end{tabular}

Note. ${ }^{* *} \mathrm{p}<0.05 ;{ }^{*} \mathrm{p}<0.1$

Store satisfaction significantly affects three out-of-stock responses (store switching and postponement at $\mathrm{p}<0.05$, and product switching at $\mathrm{p}<0.1)$. Thereby, as expected, positive effects of store satisfaction are recorded in the case of product switching (0.0373) and postponement
(0.0253) and negative effect in the case of store switching (-0.0494). These results confirm our first three hypotheses.

When it comes to the availability of alternative stores, there is significant positive effect on store switching $(0.1001)$ at $\mathrm{p}<0.05$ 
and significant negative effect on postponement $(-0.0526)$ at $\mathrm{p}<0.1$. This confirms hypotheses $\mathrm{H}_{4}$ and $\mathrm{H}_{6}$. However, although the influence of this variable on product switching response is negative, its $\mathrm{p}$ value is higher than $0.1(\mathrm{p}=0.836)$, what is not in accordance to hypothesis $\mathrm{H}_{5}$.

Concerning gender, we found a significant positive effect on store switching (0.0901) at $\mathrm{p}<0.1$, and a significant negative effect on product switching $(-0.1177)$ at $\mathrm{p}<0.05$, which supports hypotheses $\mathrm{H}_{7}$ and $\mathrm{H}_{8}$. Referring to this, female consumers, confronted with an out-of-stock situation, are more likely to switch stores and less likely to switch products.

In the case of mobility, significant negative effect was found only for cancellation response $(-0.0548)$, in support to hypothesis $\mathrm{H}_{9}$. On the other hand, with respect to store switching and postponement, we did not find significant effects for this variable. Thus, hypotheses $\mathrm{H}_{10}$ and $\mathrm{H}_{11}$ are not supported.

In addition to testing hypotheses, we have calculated the effects of store satisfaction on OOS responses for different levels of other antecedents (the availability of alternative stores, gender and mobility). As can be seen in Table 4, negative effects of store satisfaction on store switching are significant at all six levels with $\mathrm{p}<0.05$. It implies that for store satisfied consumers, regardless the availability of alternative stores, their gender and mobility, it's not likely to switch stores. Contrary, positive effects of store satisfaction on postponement response occur in all cases, whereas they are all significant (at $\mathrm{p}<0.05$ or $\mathrm{p}<0.1$ ), except for male consumers $(p=0.101)$. This indicates that, confronted with an out-of-stock situation, consumers are all more likely to postpone the purchase. Store satisfaction also has positive effects on product switching at all levels, but they are significant only for female (0.0406), consumers who don't use the car as transportation mode (0.0465) and even in the cases when there are available alternative stores (0.0440). With respect to cancellation, despite the fact that all effects are negative, none of them is significant.

Furthermore, for obtaining deeper insights into the research problem, we compared possibilities of different OOS responses in the context of analyzed variables. Table 5 presents parameter estimates for these responses, with regard to baseline responses.

Table 5

\section{Parameter estimates for OOS responses}

\begin{tabular}{lccccc}
\hline \multirow{2}{*}{ Baseline responseS } & OOS responses & \multicolumn{3}{c}{ Antecedents } \\
\cline { 3 - 6 } & Store switching & $\begin{array}{c}\text { Store } \\
\text { satisfaction }\end{array}$ & $\begin{array}{c}\text { Alternative } \\
\text { stores }\end{array}$ & Gender & Mobility \\
\hline \multirow{3}{*}{ Postponement } & $-0.5066^{* *}$ & $1.0164^{* *}$ & 0.3759 & -0.6610 \\
& Product switching & -0.2497 & 0.6168 & -0.1855 & -0.3749 \\
& Cancellation & $-0.5914^{* *}$ & -0.0769 & 0.6414 & $-1.6173^{* *}$ \\
\hline \multirow{3}{*}{ Store switching } & Product switching & $0.2568^{* *}$ & -0.3995 & $-0.5615^{* *}$ & 0.2860 \\
& Cancellation & -0.0847 & $-1.0934^{* *}$ & 0.2654 & $-0.9563^{*}$ \\
& Postponement & $0.5066^{* *}$ & $-1.0164^{* *}$ & -0.3759 & 0.6610 \\
\hline \multirow{3}{*}{ Cancellation } & Store switching & 0.0847 & $1.0934^{* *}$ & -0.2654 & $0.9563^{*}$ \\
& Product switching & $0.3416^{*}$ & 0.6938 & -0.8270 & $1.2424^{* *}$ \\
& Postponement & $0.5914^{* *}$ & 0.0769 & -0.6414 & $1.6173^{* *}$ \\
\hline \multirow{2}{*}{ Product switching } & Store switching & $-0.2568^{* *}$ & 0.3995 & $0.5615^{* *}$ & -0.2860 \\
& Cancellation & $-0.3416^{*}$ & -0.6938 & 0.8270 & $-1.2424^{* *}$ \\
& Postponement & 0.2497 & -0.6168 & 0.1855 & 0.3749 \\
\hline
\end{tabular}

Note. ${ }^{* *} \mathrm{p}<0.05 ;{ }^{*} \mathrm{p}<0.1$ 
When looking at a column with the store satisfaction antecedent, we see what happens with the probability of consumer OOS responses in comparison to reference OOS response (baseline response) as their satisfaction with stores rises. For example, the negative parameter estimate of -0.5066 suggests that, as consumer satisfaction with stores rises, the probability of store switching will be significantly smaller in comparison to the probability of postponement. The same conclusion can be reached when it comes to the probability of cancellation in comparison to postponement. On the other hand, the positive parameter estimate of 0.2568 suggests that, as consumer satisfaction with stores rises, the probability of product switching will be significantly greater in comparison to the probability of store switching.

The greatest implications are that more satisfied consumers will more likely switch products and postpone than switch stores or cancel the purchase.

When considering the remaining antecedents, Table 5 shows probabilities of consumer OOS responses in comparison to baseline response in cases when alternative stores are available, when consumers are female and when they use car. When alternative stores are available, consumers will rather switch stores than postpone or cancel the purchase. Female consumers will more likely switch products than stores, while consumers who use car will rather opt for other responses (postponement, store switching and product switching) than for cancellation.

\section{Discussion and conclusions}

Almost any consumer response to stockout events may produce adverse effects, not only for retailers but also for manufacturers. In addition to sales loses, it can cause operational problems as well. Keeping that in mind, special attention should be given to out-of-stock situations. As consequences mostly depend on consumer responses, this article presented their antecedents.
In this article, we focused on the influence of store satisfaction and the availability of alternative stores, and on gender and mobility as consumer-related factors on consumer outof-stock responses (product switching, store switching, postponement and cancellation). Moreover, we investigated the relationships between store satisfaction and these responses at both levels of all other antecedents.

The results show that store satisfaction significantly affects three out-of-stock responses (store switching, postponement and product switching), whereas, positively in the case of product switching and postponement and negatively in the case of store switching. Concerning the second store-related variable, the availability of alternative stores positively affects the probability of store switching and negatively the probability of postponement.

With regard to gender, female consumers confronted with an out-of-stock situation are more likely to switch stores and less likely to switch products. As for mobility, consumers who use cars as a transportation mode to the store are less likely to cancel the purchase.

The results also show that, for store satisfied consumers, regardless of the availability of alternative stores, gender and transportation mode, they are not likely to switch stores in the case of out-of-stocks. Confronted with such a situation, in most cases, they are more likely to switch products or postpone the purchase.

Bearing in mind that store satisfaction positively affects "more desirable" (product switching and postponement) and negatively affects "less desirable" OOS responses for retailers (cancellation), it can be considered a way to reduce negative stock-out effects. Consequently, in order to improve satisfaction levels, retailers should focus on all the influencing factors preceding the creation of the shopping experience and that affect this experience (Lovreta et al., 2010). Among them, special attention should be given to service quality and its elements (reliability, personal attention, comfort and other 
features), bearing in mind their positive impact on consumer satisfaction levels (Dabholkar, Shepherd \& Thorpe, 2000; Shemwell, Yavas, \& Bilgin, 1998). Other influential factors, such as store environment (Kaltcheva \& Weitz, 2006), customer involvement in the shopping process etc., should not be neglected either.

\section{References}

Azevedo, C., \& Araújo, O. (2004). Causas e impactos na cadeia de abastecimento e no comportamento do consumidor. Sáo Paulo: ACNielsen a VNU business.

Barajas, R. F. (2004). Optimizando la disponibilidad de producto para el consumidor. Colombia: IAC Colombia.

Bartlett, M. S. (1954). A note on the multiplying factors for various chi square approximations. Journal of the Royal Statistical Society, 16(Series B), 296-298.

Bayle-Tourtoulou, A., Laurent, G., \& Macé, S. (2006). Assessing the frequency and causes of out-ofstock events through store scanner data. Paris: HEC.

Blinder, A., \& Maccini, L. (1991). Taking stock a critical assessment of recent research on inventories. Journal of Economic Perspectives, 5(1), 73-96.

Bridson, K., Evans, J., \& Hickman, M. (2008). Assessing the relationship between loyalty program attributes, store satisfaction and store loyalty. Journal of Retailing and Consumer Services, 15(5), 364-374.

Catuogno, N. (2013, September). Sem falta. SuperVarejo, Capa Ruptura, 36-50.

Campo, K., Gijsbrechts, E., \& Nisol, P. (2000). Towards understanding consumer response to stock-outs. Journal of Retailing, 76(2), 219-242.

Dabholkar, P., Shepherd, C. D., \& Thorpe, D. I. (2000). A comprehensive framework for service quality: An investigation of critical conceptual and measurement issues through a longitudinal study. Journal of Retailing, 76(2), 139-173.

Das, G. (2014). Impacts of retail brand personality and self-congruity on store loyalty: The moderating role of gender. Journal of Retailing and Consumer Services, 21(2), 130-138.

Dholakia, R. R. (1999). Going shopping: Key determinants of shopping behaviors and motivations. International Journal of Retail and Distribution Management, 27(4), 154-166.

ECR AP. (2012). On shelf availability in Asia Pacific. Asia-Pacific: Author.

ECR Brasil. (2004). Estudo vai rastrear perdas no varejo. São Paulo: Author.

ECR Brasil. (2005). Supermercados perdem 8\% das vendas com falta de produtos e cliente troca de marca quando não encontra a que deseja. São Paulo: Author.

ECR Brasil. (2007). Como resolverlatacar o problema de rupturas em sua loja - Campanha do Bilhão - 1o Fascículo. São Paulo: Author.

ECR Europe. (2009). Living and breathing on-shelf availability: How to get break-through. Barcelona: Author.

Ehrenthal, J., Gruen, T., \& Hofstetter, J. (2014). Value attenuation and retail out-of-stocks, a service-dominant logic perspective. International Journal of Physical Distribution \& Logistics Management, 44(1/2), 39-57.

Ehrenthal, J., \& Stolzle, W. (2013). An examination of the causes for retail stockouts. International Journal of Physical Distribution \& Logistics Management, 43(1), 54-69.

Emmelhainz, M., Emmelhainz, L., \& Stock, J. (1991). Consumer responses to retail stock-outs. Journal of Retailing, 67(2), 138-147. 
Ettouzani, Y., Yates, N., \& Mena, C. (2012). Examining retail on shelf availability promotional impact and a call for research. International Journal of Physical Distribution \& Logistics Management, 42(3), 213-243.

Fernie, J., \& Grant, D. B. (2008). On-shelf availability: The case of a UK grocery retailer. The International Journal of Logistics Management, 19(3), 293-308.

Fitzsimons, G. J. (2000). Consumer response to stockouts. Journal of Consumer Research, 27(2), 249-266.

Gruen, T., Corsten, D., \& Bharadwaj, S. (2002). Retail out-of-stocks a worldwide examination of extent, causes and consumer responses. Washington: Grocery Manufacturers of America, The Food Marketing Institute and CIES.

Gruen, T., \& Corsten, D. (2007). A comprehensive guide to retail out-of-stock reduction in the fastmoving consumer goods industry. Colorado: Grocery Manufacturers. Association.

Hausruckinger, G. (2006). Approaches to measuring on-shelf availability at the point of sale. München: ECR Europe.

Helm, R., Hegenbart, T., \& Endres, H. (2013). Explaining costumer reactions to real stockouts. Review of Managerial Science, 7(3), 223-246.

Holman, L., \& Buzek, G. (2008). What's the deal with out-of-stocks? Franklin: IHL Group.

Homburg, C., Koschate, N., \& Hoyer, W. D. (2005). Do satisfied customers pay more? A study of the relationship between customer satisfaction and willingness to pay. Journal of Marketing, 69(2), 84-96.

Hu, L., \& Bentler, P. M. (1999). Cutoff criteria for fit indexes in covariance structure analysis: Conventional criteria versus new alternatives. Structural Equation Modeling: A Multidisciplinary Journal, 6(1), 1-55.
Institute of Grocery Distribution. (2007). ECR UK availability 2007. Radlet, UK: Author.

Jacobs, F. R., Berry, W. L., Whybark, D. C., \& Vollmann, T. E. (2011). Manufacturing planning and control for supply chain management. New York: McGraw-Hill.

Kaltcheva, V. D., \& Weitz, B. A. (2006). When should a retailer create an exciting store environment? Journal of Marketing, 7O(1), 107-119.

Kaiser, H, F. (1960). The application of electronic computers to factors analysis. Educational and Psychological Measurement, 20(1), 141-151.

Kaiser, H. F. (1970). A second generation Little Jiffy. Psychometrika, 35(4), 401-415.

Kaiser, H. F. (1974). An index of factorial simplicity. Psychometrika, 39(1), 31-36.

Lovreta, S., Petkovic, D., Berman, B., Veljkovic, S., Crnkovic, J., \& Bogetic, Z. (2010). Menadžment odnosa sa kupcima. Beograd: Datastatus.

Messinger, P. R., \& Narasimhan, C. (1997). A model of retail formats based on consumers economizing on shopping time. Marketing Science, 16(1), 1-23.

Milicevic, N., \& Grubor, A. (2015). The effect of backroom size on retail product availability - operational and technological solutions. The Amfiteatru Economic Journal, 17(39), 661-675.

Nunnally, J. C. (1978). Psychometric theory (2nd ed.). New York: McGraw-Hill.

Oliveira, R. (2004). Falta de produtos provoca perda de 8\% nas vendas. São Paulo: ECR Brasil, Gazeta Mercantil.

Olofsson, K. (2006). On-shelfavailability makingit-happen together. Stockholm: ECR Europe.

Papakiriakopoulos, D., \& Doukidis, G. (2011). Classification performance for making decisions 
about products missing from the shelf. Advances in Decision Sciences, 1-13.

Patterson, P. G., \& Smith, T. (2003). A crosscultural study of switching barriers and propensity to stay with service provider. Journal of Retailing, 79(2), 107-120.

Peckham, J. (1963). The consumer speaks. Journal of Marketing, 27(4), 21-26.

Progressive Grocer. (1968, October). The outof-stock study: Part 1 (pp. 4-5). New York: The Nielsen Company.

Ribeiro, C. M. (2008, maio). A ruptura de produtos nas gôndolas de varejos alimentícios: Um problema enfrentado por redes de varejo alimentício. Anais do Encontro de Marketing da ANPAD, Curitiba, Paraná, Brazil, 3.

Roland Berger Strategy Consultants. (2003). ECR: Optimal shelf availability increasing shopper satisfaction at the moment of truth. Munich: Author.

Schary, P., \& Christopher, M. (1979). The anatomy of a stock-out. Journal of Retailing, 55(2), 59-67.

Seiders, K., Voss, G. B., Grewal, D., \& Godfrey, A. L. (2005). Do satisfied customers buy more? Examining moderating influences in a retailing context. Journal of Marketing, 69(4), 26-43.

Shemwell, D. J., Yavas, U., \& Bilgin, Z. (1998). Customer service provider relationship: An empirical test of a model of service quality, satisfaction and relationship-oriented outcome. International Journal of Service Industry Management, 9(2), 155-168.

Sloot, L., Verhoef, P. C., \& Franses, P. H. (2002). The impact of brand and category characteristics on consumer stock-out reactions. Rotterdam: ERIM.

Sloot, L., Verhoef, P., \& Franses, P. (2005). The impact of brand equity and the hedonic level of products on consumer stock-out reactions. Journal of Retailing, 81(1), 15-34.

Sudarevic, T., Milicevic, N., Pupovac, L. J., \& Vukmirovic, G. (2012, May). Empirical evidence of customer reactions to out-of-stock situations. Proceedings of the Cross-Cultural Conference, Steyr, Austria.

Supermarket Guru Consumer Panel. (2011). Shoppers cite store annoyances. Woodlands: Supermarket News.

Vasconcellos, L. H. R., \& Sampaio, M. (2009). The stockouts study: An examination of the extent and the causes in the Sáo Paulo supermarkets sector. Brazilian Administration Review, 6(3), 263-279.

Verbeke, W., Farris, P., \& Thurik, R. (1998). Consumer response to the preferred brand stockout situation. European Journal of Marketing, 32(11), 1008-1028.

Verhoef, P., \& Sloot, L. (2006). Out-of-stock reactions, antecedents, management solutions, and a future perspective: Retailing in the 21st century current and future trends. Berlin: Springer.

Walter, C. K., \& Grabner, J. (1975). Stockout models empirical tests in a retail situation. Journal of Marketing, 39(3), 56-68.

Williams, R. (2012). Using the margins command to estimate and interpret adjusted predictions and marginal effects. The Stata Journal, 12(2), 308-331.

World Bank. (2010, February). How to decrease freight logistics costs in Brazil [Report n. 46885BR]. World Bank, Washington, DC.

Zinn, W., \& Liu, P. (2001). Consumer response to retail stockouts. Journal of Business Logistics, 22(1), 49-71. 
About the authors:

1. Aleksandar Grubor, PhD in Economics, University of Novi Sad, Subotica, Republic of Serbia.

E-mail: agrubor@ef.uns.ac.rs

ORCID

(iD) 0000-0001-9798-0401

2. Nikola Milicevic, PhD in Economics, University of Novi Sad, Subotica, Republic of Serbia.

E-mail: milicevic.nikola@ef.uns.ac.rs

ORCID

(iD) 0000-0003-4834-6994

3. Nenad Djokic, PhD in Economics, University of Novi Sad, Subotica, Republic of Serbia.

E-mail: djokicn@ef.uns.ac.rs

ORCID

(iD) 0000-0001-8229-8354

\section{Contribution of each author:}

\begin{tabular}{|c|c|c|c|}
\hline Contribution & Aleksandar Grubor & Nikola Milicevic & Nenad Djokic \\
\hline 1. Definition of research problem & $\sqrt{ }$ & $\sqrt{ }$ & \\
\hline $\begin{array}{l}\text { 2. Development of hypotheses or research questions (empirical } \\
\text { studies) }\end{array}$ & $\sqrt{ }$ & $\sqrt{ }$ & \\
\hline 3. Development of theoretical propositions (theoretical work) & $\sqrt{ }$ & $\sqrt{ }$ & \\
\hline 4. Theoretical foundation / Literature review & $\sqrt{ }$ & $\sqrt{ }$ & \\
\hline 5. Definition of methodological procedures & $\sqrt{ }$ & & $\sqrt{ }$ \\
\hline 6. Data collection & & $\sqrt{ }$ & $\sqrt{ }$ \\
\hline 7. Statistical analysis & & & $\sqrt{ }$ \\
\hline 8. Analysis and interpretation of data & & & $\sqrt{ }$ \\
\hline 9. Critical revision of the manuscript & $\sqrt{ }$ & & $\sqrt{ }$ \\
\hline 10. Manuscript writing & & $\sqrt{ }$ & $\sqrt{ }$ \\
\hline
\end{tabular}

